\title{
BIMBINGAN AGAMA ISLAM DALAM MENINGKATKAN KETENANGAN JIWA WARGA BINAAN \\ DI LEMBAGA PERMASYARAKATAN
}

\author{
Zulkifli, b \\ Universitas Islam Negeri (UIN) Raden Intan Lampung \\ Jl. Letnan Kolonel H, Endro Suratmin, Sukarme,lampung 35131 \\ Zulkifli.b62@gmail.com
}

\begin{abstract}
Abstrack
Humans are the most perfect creatures that God created compared to others, because humans have thoughts and feelings that other creatures do not have. God revealed Islam as a guide for humans so they would not be easily lost. Religion is a benchmark for someone to do an act, because in religion there are rules that God gives in living life. The rules are not limited to human relations with God, but the rules of relations between humans and relations with their environment. Symptoms of insecurity in one's soul are easily anxious, fearful, emotional overflowing and uncontrollable, so that he cannot be friends with himself or with other people. Someone needs a mentor in the process of self-recognition and religion. It takes a variety of processes to get to know the religion of Islam, namely with the help of a counselor who provides an understanding that can be accepted by the person so that it becomes a reference in life, then someone who has a calm soul is protected from symptoms of mental disorders. Good religious formation, theoretically will produce good results for humans. Likewise religious guidance for good female prisoners will also give birth to the character of prisoners for themselves and the community. However, the phenomena found are still some of those who were netted in the same case several times, which are clearly prohibited by religious and community norms
\end{abstract}

Keywoard: Islamic guidance, peace of mind 


\section{A. PENDAHULUAN}

Manusia adalah makhluk paling sempurna yang Allah ciptakan dibandingkan dengan lainnya, karena manusia memiliki pikiran dan perasaan yang tidak dimiliki oleh makhluk lainnya. Allah menurunkan agama lslam sehagai penuntun jalan bagi manusia agar mereka tidak mudah tersesat. Agama merupakan tolak ukur bagi seseorang untuk melakukan suatu perbuatan, karena di dalam agama terkandung aturan yang Allah berikan dalam menjalani hidup. Aturan tersehut bukan sebatas hubungan manusia dengan Allah, tetapi aturan hubungan antara manusia dan hubungan dengan lingkungannya.

Gejala-gejala tidak tenang jiwa seseorang adalah mudah cemas, takut, emosi yang meluapaluap dan tidak terkendali, sehingga ia tidak dapat bersahabat dengan diri sendiri ataupun dengan orang lain. Seseorang membutuhkan pembimbing dalam proses pengenalan diri dan agama. Dibutuhkan berbagai proses untuk mengenal agama Islam, yakni dengan bantuan pembimbing yang memberikan pemahaman yang dapat diterima oleh orang tersebut sehingga dijadikan acuan dalam hidup, maka seseorang yang memiliki jiwa tenang terhindar dari gejala gangguan-gangguan jiwa. Manusia yang mempunyai kelainan jasmani dan mental, biasanya mereka memiliki perilaku abnormal seperti sosiapatik (tidak dapat menyesuaikan diri), penyimpangan sosial yang dapat melakukan hal-hal kriminal atau melanggar aturan dan norma. Seseorang yang melanggar aturan dan norma seperti di Indonesia dapat dikenakan hukuman dan sanksi sesuai undang-undang yang telah ditetapkan. Seseorang yang telah terbukti bersalah Seperti judi, mencuri, membunuh, korupsi, dan tindakan kriminal lainnya akan mendapatkan hukuman dipenjara dan orang tersebut dikenal dengan sebutan narapidana atau warga binaan ${ }^{1}$.

Pembinaan keagamaan yang baik, secara teoritis akan melahirkan hasil binaan yang baik untuk manusia. Begitu pula pembinaan keagamaan pada narapidana wanita yang baik, juga akan melahirkan karakter narapidana baik bagi dirinya sendiri dan masyarakat. Akan tetapi, fenomena yang ditemukan masih ada juga sebagian dari mereka yang terjaring dalam kasus yang

${ }^{1}$ Wiryo Setiana, Patologi Sosial, Bandung, Mimbar Pustaka, 2012, h.114 
sama beberapa kali, yang nyata-nyata dilarang oleh normanorma agama dan masyarakat berbagai alasan mereka kembali ke tindak kejahatan tersebut dikarenakan sebagai berikut:

1.Gangguan Psikis : (balas dendam, frustasi, petualangan, broken home, dll.)

2.Gangguan Ekonomi :(tekanan ekonomi keluarga, krisis moneter, dll.)

3.Gangguan Budaya :(lingkungan tempat tinggal, pelanggaran norma sosial atau budaya, pelanggaran norma agama, dll.) ${ }^{2}$

Banyak permasalahan dan menjadi konflik bagaimana untuk mengembalikan dan memulihkan kepercayaan diri, harga diri, harkat dan martabat para narapidana ke kehidupan masyarakat kelak dan layak, serta secara normatif sesuai dengan norma ajaran Islam, maka perlu didekati dengan sentuhan nilainilai agama Islam. Sejalan dengan ini, maka pembinaan keagamaan sangat berperan dalam rangka mempercepat proses rehabilitasi tersebut. Inti pelaksanaan pembinaan keagamaan adalah penjiwaan agama dalam hidupnya, Ia dibina sesuai dengan tingkat dan situasi psikologisnya. ${ }^{3}$

Bimbingan agama Islam merupakan salah satu bimbingan yang tepat untuk Seseorang yang kurang mendapatkan ketenangan jiwa. Melalui bimbingan agama, seseorang akan mendapatkan ketenangan jiwa sehingga tindakannya dan perbuatan narapidana sesuai dengan Syariat Allah Swt. Bagi warga binaan yang telah terbukti melakukan tindak pidana korupsi dan tlndak kriminal lainnya untuk dewasa muda. Pada tanggal 22 Juni 2010 telah dilakukan penandatanganan Prasasti oleh Menteri Hukum dan Hak Asasi Manusia Republik Indonesia.Kementrian Hukum dan Hak Asasi Manusia. Mempunyai tugas melakukan pembinaan guna meningkatkan kualitas narapidana, meliputi kualitas ketakwaan kepada Tuhan Yang Maha Esa; kualitas intelektual, kualitas sikap dan perilaku; kualltas profesionalisme; dan kualitas kesehatan jasmani dan rohani Serta kualitas keamanan dalam pelayanan. Misi lapas melaksanakan pembinaan sekaligus mempersiapkan warga binaan agar siap kembali ke masyarakat dan menjadi manusia

2 Kartono, Psikologi Anak, Bandung: Alumni, 1982, h.222

3 Arifin, Pokok-Pokok Pikiran Tentang Bimbingan Penyuluhan Agama, Jakarta : Bulan Bintang. 1977, h.13 
yang berperan aktif dalam pembangunan negara melalui program.

a. Pembinaan ronani (mental) dalam agama dan emosional.

b. Pembinaan keterampilan (soft skill) yang kebutuhan di masyarakat.

c. Perlindungan terhadap Hak Asasi Manusia bagi warga binaan.

d. Menjaga keamanan bagi masyarakat, petugas, dan warga binaan.

e. Menjadi Lapas yang akuntabel dan pelayanan prima bagi publik.

Terdapat dua kategori yang menjadi warga binaan (narapidana) di Lapas yaitu, orang yang sengaja melakukan tindakan kriminal, sehingga dia menjadi warga binaan Lapas dan orang yang tidak sengaja melakukan hal yang dianggap kriminal sehingga menyebabkan dia menjadi warga binaan di Lapas. mengadakan program bimbingan agama Islam untuk warga binaan yang beragama Islam. Awalnya program ini wajib diikuti setiap warga binaan yang beragama Islam. Namun, saat ini program tersebut hanya diwajibkan tiga bulan pertama masuk menjadi warga binaan untuk mengetahui proses yang terjadi Serta mengetahui metode dan materl yang diberikan dan hasil dari bimbingan agama Islam terhadap pemahaman dan kesadaran dalam beragama.

\section{B. BIMBINGAN AGAMA ISLAM}

Bimbingan adalah arahan, tuntunan ${ }^{4}$. Konsep Dasar Bimbingan dan Konseling", makna bimbingan adalah suatu proses pemberian bantuan kepada individu yang dilakukan secara terus menerus, supaya individu tersebut dapat memahami dirinya, sehingga ia sanggup mengarahkan diri dan bertindak wajar sesuai dengan tuntunan dan keadaan sekolah, lingkungan, keluarga dan masyarakat, dengan demikian mereka dapat mengecap kebahagiaan hidupnya serta dapat memberikan sumbangan yang berarti kapada kehidupan masyarakat umumnya ${ }^{5}$. menyebutkan bahwa bimbingan berarti pemberian

4Peter Salim \& Yenny Salim, Kamus Bahasa Indonesia Kontemporer, Jakarta: Modern English Press,1991, h.205.

5Salcha Hatras, Konsep Dasar Bimbingan dan Konseling, Surakarta:FKIP UNS, 1999, h.2. 
bantuan kepada orang atau sekelompok orang dalam membuat pilihan-pilihan secara bijaksana dalam mengadakan penyesuian diri terhadap tuntutan-tuntutan hidup. Bantuan itu bersifat psikis (kejiwaan), bukan pertolongan finansial, medis dan sebagainya. Dengan bantuan ini, seseorang akhirnya dapat mengatasi sendiri masalah yang dihadapinya sekarang dan menjadi lebih mampu untuk menghadapi masalah yang akan dihadapi kelak ${ }^{6}$

Bimbingan berasal dari istilah Inggris "Guidance"yang berasal dari kata "to guide" yang artinya menunjukkan, membimbing atau menuntun orang lain kejalan yang benar ${ }^{7}$.Penegertian bimbingan secara luas ialah suatu proses pemberian bantuan yang terus menerus dan sistematis kepada individu dalam memecahkan masalah yang dihadapinya, agar tercapai kemampuan untuk memahami dirinya, mampu menerima dirinya, mampu untuk mengarahkan dirinya dan mampu menyesuaikan diri dengan linkungannya, baik dalam keluarga, sekolah maupun masyarakat ${ }^{8}$.

Bimbingan suatu proses yang terus menerus dalam membantu perkembangan individu untuk mencapai kemampuannya secaramaksimal dalam mengarahkan manfaat yang sebesar-besarnya baik bagi dirinya maupun bagi masyarakat ${ }^{9}$. Bimbingan adalah bantuan kepada seseorang dalam proses pemahaman dan penerimaan terhadap kenyataan yang ada pada dirinya sendiri serta perhitungan(penilaian) terhadap lingkungan sosio-ekonominya masa sekarang dan kemungkinan masa mendatang dan bagaimana mengintegrasikan dua hal tersebut melalui pilihan-pilahan diri yang membawa pada keputusan hidup pribadi dan kedaya gunaan hidup ekonomi sosial. Bimbingan adalah pemberian bantuan yang dilakukan secara sadar, berencana, terus menerus dalam upaya pengembangan kepribadian seseorang yang

6 W.S. winkel, Bimbingan dan Konseling di Sekolah, Jakarta: PT Gramedia,1984, h.20.

7 M. Arifin, Pokok-Pokok Pikiran Bimbingan dan Penyuluhan Agama, Jakarta:Bulan Bintang,1978,h.18

8 Khoirul Umam \& A. Achyar Aminudin, Bimbingan dan Penyu luhan, Bandung: CV Pustaka Setia.1998, h.12

9 M. Arifin, Pokok-Pokok Pikiran Bimbingan dan Penyuluhan Agama, Jakarta:Bulan Bintang,1978,h..31 
tercermin pada sikap dan perbuatan dalam kehidupan seharihari

Agama adalah kepercayaan kepada Tuhan, sifat-sifat serta kekuasaan-Nya dengan ajaran dan kewajiban-kewajiban yang berhubungan dengan kepercayaan $i^{1}{ }^{10}$. Dalam pengertian yang sederhana agama adalah proses hubungan manusia yang dirasakan terhadap sesuatu yang diyakininya, bahwa itu lebih tinggi dari manusia ${ }^{11}$.Sedangkan Islam yaitu agama yang diajarkan oleh Nabi Muhammad SAW yang berpedoman pada kitab suci Al-Qur'an atas perintah Allah ${ }^{12}$. Namun umumnya ulama' mendefinisikan Islam adalah wahyu Allah yang disampaikan kepada Nabi Muhammad SAW untuk kebahagian umat manusia di dunia dan akhirat ${ }^{13}$.

Dari penjelasan di atas dapat disimpulkan bahwa bimbingan agama Islam adalah merupakan proses pemberian bantuan yang dilakukan secara terus menerus dan berkesinambungan untuk membina, membangun, mengembangkan serta membantu kepada seseorang atau sekelompok orang agar dapatmenyelesaikan permasalahan yang sedang dihadapinya serta dapat membuat pilihan-pilihan secara bijaksana dalam penyesuaian diri terhadap tuntutan-tuntutan hidup. Bantuan ini bersifat psikologis (kejiwaan) dan berdasar pada ajaran-ajaran agama Islam yang berpedoman pada AlQu' an dan Hadits.

Unsur-Unsur dalam Bimbingan Agama Islam

1. Subyek

Subyek adalah pelaku pekerjaan, atau dalam hal ini adalah orang yang melaksanakan bimbingan agama Islam atau orang yang mempunyai kemampuan dalam menyampaikan maksud dan tujuan pelaksanaan bimbingan agama Islam terhadap narapidana. Untuk menjadi seorang konselor atau pembimbing harus memenuhi syarat-syarat sebagai berikut:

10Peter Salim \& Yenny Salim, Kamus Bahasa Indonesia Kontemporer, Jakarta: Modern English Press,1991, h.18

11 Zakiyah Daradjat, Ilmu Jiwa Agama, Jakarta: Bulan Bintang, 1996, h.24.

12Peter Salim \& Yenny Salim, Kamus Bahasa Indonesia Kontemporer, Jakarta: Modern English Press,1991, h. 581.

${ }^{13}$ Khoirudin Nasution, Pengantar Studi Islam, Yogyakarta:Academia + Tazzafa, 2004, h.2 
a.Menaruh minat mendalam terhadap orang lain dan penyebaran b.Peka terhadap sikap dan tindakan orang lain c.Memiliki kehidupan emosi yang stabil dan obyektif, d.Memilikikemampuan dan dipercaya orang lain e. Menghargai fakta ${ }^{14}$

2. Obyek

Obyek yaitu yang menjadi sasaran atau yang dibin a(yang mendapat pembinaan), dalam hal ini yaitu para narapidana yang sekarang berada dalam lembaga pemasyarakatan.

\section{Materi}

Yang dimaksud dengan materi adalah semua bahanbahan yang akan disampaikan kepada terbina. Jadi yang dimaksud materi di sini adalah semua bahan yang dapat dipakai untuk bimbingan agama Islam. Materi dalam bimbingan agama Islam yaitu semua yang terkandung dalam al-Qur'an yaitu: akidah, akhlak, dan hukum ${ }^{15}$, adapun materinya:

a. Aqidah atau Keyakinan.

Merupakan fundamen bagi setiap muslim, dalam arti menjadi landasan yang memberi corak serta arah bagi kehidupan seoarang muslim ${ }^{16}$. Aqidah adalah kepercayaan yang wajib diyakini kebenarannya oleh setiap muslim yang dirumuskan dalam ajaran "enam rukun Iman" yakni Iman kepada Allah, malaikat, kitabkitab, para Nabi dan Rasul-Rasul-Nya serta hari akhir ${ }^{17}$

b. Akhlak atau Moral.

Akhlak atau moral merupakan pendidikan jiwa agar seseoarang dapat bersih dari sifat-sifat yang tercela dan dihiasi dengan sifat-sifat yang terpuji. Menurut Imam AlGhozali dalam Ihya' Ulumuddin, akhlaq adalah sifat yang tertanam dalam jiwa dari padanya timbul

${ }^{14}$ Singgih D Gunarsa, Konseling dan Psikoterapi, Jakarta: Gunung Mulia,1992, h.64.

${ }^{15}$ M. Quraish Shihab, Membumikan A-Qur'an: Fungsi dan Peran Wahyu dalam Kehidupan Masyarakat, Bandung:PT Mizan Pustaka,2007, h.303.

${ }_{16}$ M. Mashur Amin, Metode Dakwah Islamiyah, Yogyakarta: Sumbangsih, 1980, h.17

${ }^{17}$ Nasrudin Razak, Dienul Islam, Bandung: PT. Al-Maarif, 1996, h.39. 
perubahahn yang mudah tanpa memerlukan pertimbangan pikiran ${ }^{18}$

c. Hukum atau Syari' ah .

Hukum atau Syari'ah merupakan peraturan-peraturan yang disyariatkan oleh Allah untuk pegangan bagi umat manusia, baik secara terperinci maupun global. Dan juga mengatur hubungan antara makhluk dengan Tuhannya.Yaitu: 1.Ibadah yaitu aturan agama yang mengatur hubungan manusia dengan Tuhan, yang dirumuskan dalam "lima rukun Islam" yakni: Syahadat, Sholat, Puasa, Zakat dan Haji. Ibadah merupakan manifestasi iman umat Islam yang berpedoman pada AlQur'an dan Hadits dan kesepakatan Ulama (Ijma').

\section{KETENANGAN JIWA}

Kata ketenangan jiwa terdiri dari kata ketenangan dan jiwa. Sedangkan kata ketenangan itu sendiri berasal dari kata tenang yang mendapat sufiks ke-an. Tenang berarti diam tak berubahubah (diam tak bergerak-gerak); tidak gelisah, tidak rusuh, tidak kacau, tidak ribut, aman dan tenteram (tentang perasaan hati, keadaan dan sebagainya). Tenang, ketenteraman hati, batin, pikiran ${ }^{19}$, sedangkan jiwa adalah seluruh kehidupan batin manusia yang menjadi unsur kehidupan, daya rohaniah yang abstrak yang berfungsi sebagai penggerak manusia dan menjadi simbol kesempurnaan manusia (yang terjadi dari hati, perasaan, pikiran dan angan-angan). Kata ketenangan jiwa juga dapat diartikan sebagai kemampuan untuk menyesuaikan diri sendiri, dengan orang lain, masyarakat dan lingkungan serta dengan lingkungan di mana ia hidup, sehingga orang dapat menguasai faktor dalam hidupnya dan menghindarkan tekanan-tekanan perasaan yang membawa kepada frustasi ${ }^{20}$.

Jadi ketenangan jiwa atau kesehatan mental adalah kesehatan jiwa, kesejahteraan jiwa, atau kesehatan mental.

\section{h.31.}

18 Nasrudin Razak, Dienul Islam, Bandung: PT. Al-Maarif, 1996,

19 Tim Penyusun Kamus Pusat Pembinaan Dan Pengembangan Bahasa, Kamus Besar Bahasa Indonesia, Jakarta: Balai Pustaka, 2004, h. 927.

20 Zakiah Daradjat, Kesehatan Mental, Jakarta: Gunung Agung, 2006, h. 11 
Karena orang yang jiwanya tenang, tenteram berarti orang tersebut mengalami keseimbangan di dalam fungsi-fungsi jiwanya atau orang yang tidak mengalami gangguan kejiwaan sedikitpun sehingga dapat berfikir positif, bijak dalam menyikapi masalah, mampu menyesuaikan diri dengan situasi yang dihadapi serta mampu merasakan kebahagiaan hidup.

\section{WARGA BINAAN}

Kegiatan untuk melakukan pembinaan Warga Binaan Pemasyarakatan berdasarkan sistem, kelembagaan, dan cara pembinaan yang merupakan bagian akhir dari sistem pemidanaan dalam tata peradilan pidana"21 Maksudnya, pemasyarakatan sebagai bagian akhir dari proses peradilan pidana dan dalam melaksanakan pidananya diberi suatu pembinaan yang ditujukan terhadap narapidana sebagai Warga Binaan Pemasyarakatan

Menurut Pasal 1 Angka 5 UU Nomor 12 Tahun 1995 Tentang Pemasyarakatan, bahwa Warga Binaan Pemasyarakatan adalah Narapidana, Anak Didik Pemasyarakatan, dan Klien Pemasyarakatan. Adapun Narapidana adalah terpidana yang menjalani pidana hilang kemerdekaan di Lembaga Pemasyarakatan (UU RI No. 12 Th. 1995 tentang Pemasyarakatan Pasal 1 ayat 7$)$.

1. Peraturan Pemerintah Nomor 31 Tahun 1999 sebagai berikut:

(1) Program pembinaan dan pembimbingan meliputi kegiatan pembinaan dan pembimbingan kepribadian dan kemandirian

(2) Program pembinaan diperuntukkan bagi narapidana dan anak didik pemasyarakatan

(3) Program pembimbingan diperuntukkan bagi klien

Pasal 3 menyatakan pembinaan dan pembimbingan kepribadian dan kemandirian sebagaimana dimaksud dalam Pasal 2 meliputi hal-hal yang berkaitan dengan:

a. Ketaqwaan kepada Tuhan Yang Maha Esa;

b. Kesadaran berbangsa dan bernegara;

c. Intelektual;

d. Sikap dan perilaku;

e. Kesehatan jasmani dan rohani;

21 Soerjono Soekanto. 2002. Sosiologi Suatu Pengantar. Jakarta : Rajawali Press, h. 3 

f. Reintegrasi sehat dengan masyarakat
g. Keterampilan kerja dan;
h. Pelatihan kerja dan produksi

2. Keputusan Menteri Kehakiman Nomor: M. 02. PK.04-10 Tahun 1900 tanggal 10 April 1990 tentang Pola Pembinaan Narapidana/Tahanan yang meliputi 2 bentuk pembinaan yaitu:

a. Pembinaan Kepribadian

Pembinaan kepribadian diwujudkan dalam program-program:

1) Pembinaan kesadaran beragama/ketaqwaan kepada Tuhan Yang Maha Esa

2) Pembinaan Kesadaran Berbangsa dan Bernegara

3) Pembinaan Kemampuan intelektual, baik formal maupun informal

4) Pembinaan kesadaran hukum

b. Pembinaan Kemandirian

Pembinaan kemandirian diwujudkan dalam program:

1) Keterampilan untuk mendukung usaha-usaha mandiri, misalnya kerajinan tangan, industri rumah tangga, reparasi mesin dan alat-alat elektronik dan lain-lain

2) Ketrampilan untuk mendukung usaha-usaha industri kecil misalnya, pengelolaan bahan mentah dari sektor pertanian dan bahan alam menjadi bahan setengah jadi.

3) Ketrampilan yang dikembangkan sesuai dengan bakat masing-masing misalnya kemampuan di bidang seni (lukis, tari, musik peran, dan lain-lain)

4) Ketrampilan yang mendukung usaha-usaha industri, pertanian, perikanan, peternakan, perkebunan dan lain-lain.

Berpijak kepada kedua aturan di atas maka kegiatan pembinaan narapidana di Lembaga Pemasyarakatan dibagi menjadi:

a. Pembinaan Kepribadian yang meliputi:

1) Pembinaan kesadaran beragama 
2) Pembinaan kesadaran berbangsa dan bernegara serta kesadaran hukum

3) Pembinaan kemampuan intelektual

4) Pembinaan rekreasi

5) Pembinaan mengintegrasikan diri dengan masyarakat

b. Pembinaan Kemandirian yang meliputi:

1) Pertanian dalam

2) Anyam bambu

3) Pembuatan paving blok

4) Pertukangan kayu

5) Pembuatan keset

Pembinaan kesadaran beragama yang merupakan hak para narapidana telah terlaksana sesuai dengan ketentuan yang ada. Pembinaan seperti ini adalah sesuatu bentuk pembinaan yang diberikan kepada narapidana agar mereka dapat membedakan mana yang benar dan mana yang salah menurut ketentuan aturan yang digariskan oleh agama mereka masing-masing atau dengan kata lain agar dapat menjadi manusia yang taat kepada peraturan agama. Kegiatan keagamaan yang disampaikan kepada kepada narapidana disesuaikan dengan agama yang dianutnya.

\section{E. PROSES BIMBINGAN ISLAM DI LAPAS}

Proses bimbingan Islam Dalam Kerangka Pembinaan Narapidana Di Lembaga Pemasyarakatan dilakukan secara terencana, terarah dan terpadu. Terencana, yaitu implementasi ajaran agama Islam dalam kerangka pembinaan bagi narapidana di Lembaga Pemasyarakatan yang antara lain meliputi kegiatan sholat dan pengajian diselenggarakan secara terjadwal setiap hari.Baik terjadwal mengenai waktu maupun materinya. Terarah, artinya implementasi ajaran agama Islam dalam kerangka pembinaan bagi narapidana di Lembaga Pemasyarakatan terarah pada perbaikan mental narapidana agar tidak mengulangi mkesalahannya. Terpadu,yaitu mengenai arah dan batas, serta cara pembinaan narapidana berdasarkan Pancasila yang dilaksanakan antara pembina, yang dibina dan masyarakat, untuk meningkatkan kualitas warga binaan 
agar menjadimanusia seutuhnya, bertakwa, sehat dan bertanggung jawab pada diri, keluarga dan masyarakat, sehingga dapat mengintegrasikan dirinya ke dalam masyarakat dan dapat kembali berperan sebagai anggota masyarakat yang bebas dan bertanggung jawab.

Pada metode nasehat ini, memperoleh data dari pengamatan yang penulis lakukan sewaktu observasi di Lapas. Saat peneliti mengikuti pelaksanaan pendidikan agama Islam di Lapas, pembimbing keagamaan (Ustadz) bukan hanya memberikan penjelasan-penjelasan tentang materi tetapi juga memberikan nasehat kepada warga binaan untuk dapat menjadi orang yang lebih baik lagi. Penulis lakukan tentang metode pelaksanaan pendidikan agama Islam berupa untuk wargabinaan umum di Lapas diperoleh hasil sebagai berikut:

1) Metode Ceramah

Metode ceramah ini digunakan pada mayoritas materi pendidikan agama Islam di Lapas. Seperti dalam materi tauhid, materi akhlak, materi fiqh, materi tafsir, materi hadits dan materi tasawuf.

2) Metode Qiro'ah

Metode Qiro'ah ini digunakan pada materi BTA.Karena dalam materi BTA warga binaan tidak hanya dituntut untuk mendengarkan pembimbing tetapi juga membaca dan menirukan apa yang diucapkan pembimbing.

3) Metode Pembiasaan

Metode pembiasaan ini adalah sebuah metode yang digunakan untuk mebiasakan warga binaan pada hal-hal baik. Seperti sholat lima waktu berjamaah, membaca AlQur'an, dan berprilaku sopan.

4) Metode Nasehat

Metode nasehat ini digunakan pada seluruh materi. Seperti dalam materi tauhid, materi BTA, materi akhlak, materi fiqh, materi tafsir, materi haditsdan materi tasawuf. Karena dalam penyampaian pokok bahasan tertentu tertapat bagian-bagian atau waktu yang tepat untuk pembimbing memberikan kepada warga binaan. Seperti materi tentang taubat, makanan yang halal dan 
haram, tentang judi dan khamar, tentang keutamaan sholat dan tentang keesaan Allah. ${ }^{22}$

1. Hambatan dan Solusi dalam pelaksanaan bimbingan Islam di Lapas lapas.

Untuk jumlah pembinanya sendiri masing-masing dari beberapa pihak tadi dalam melakukan pembinaan agama Islam di Lembaga Pemasyarakatan jumlahnya berbeda. Begitu pula yang bertugas untuk memberikan pembinaan juga terkadang bergantian.Adapun jadwal implementasi Ajaran Agama Islam berupa kegiatan iqrodi masjid AtTawbah, Lembaga Pemasyarakatan diharapkan dapat memperlancar proses bimbingan dan pembinaan ajaran agama Islam bagi narapidana dan diharapkan narapidana ada peningkatan moralitas yang lebih baik.

Selain faktor-faktor di atas, ada beberapa faktor pendukung lain dalam pembinaan agama Islam bagi narapidana di Lembaga Pemasyarakatan yaitu:

a. Masjid

Dengan adanya masjid yang terletak di dalam blok semua penghuni Lembaga Pemasyarakatan mempunyai ruang khusus yang dapat digunakan sebagai tempat ibadah danuntuk kegiatan lainnya.

b. Alat perlengkapan sholat.

Agar proses implementasi ajaran Agama Islam dapat berjalan dengan baik adapun alat perlengkapan yang disediakan oleh Lembaga Pemasyarakatan sebagai sarana pelengkap sholat. Seperti sajadah dan karpet.

c. Perlengkapan belajar mengajar Adanyapembinaan narapidana dengan kegiatan-kegiatan keagamaan yang dilakukan oleh Lembaga Pemasyarakatan seperti praktek dakwah, belajar baca tulis Al-Qur'an dan sebagainya maka Lembaga Pemasyarakatan juga menyediakan perlengkapan belajar mengajar sebagai sarana pendukung kegiatan tersebut, yaitu dengan adanya meja kecil untuk belajar baca tulis Al-Qur'an, papan tulis, spidol, penghapus, juz Amma, iqro dan Al-Qur'an.

${ }^{22}$ Dokumentasi kurikulum PAI Lapas Pekalongan, 23 Oktober 2016. 
Faktor Penghambat dan solusi dalam Pelaksanaan bimbingan Islam Dalam Kerangka Pembinaan Narapidana Di Lembaga Pemasyarakatan

a. Keterbatasan bangunan.

Lembaga Pemasyarakatan yang terletak di tengah-tengah sangat mempengaruhi jumlah bangunannya. Dengan lahan Lembaga Pemasyarakatan yang minim maka bangunan yang dimiliki oleh Lembaga Pemasyarakatan sangat terbatas. Maka dapat disimpulkan bahwa tanpa adanya bangunan yang dikhususkan untuk ruang baca atau perpustakaan sangat menghambat dalam proses implementasi ajaran agama Islam dalam kerangka pembinaan narapidana di Lembaga Pemasyarakatan, maka solusinya diharapkan agar pihak Pemerintah Pusat dapat menambah bangunan khusus ruang baca atau perpustakaan di Lembaga Pemasyarakatan dengan tujuan untuk mengatasi hambatan dalam proses pembinaan ajaran agama Islam yang timbul dikarenakan keterbatasan bangunan yang ada.

b. Sarana atau Prasarana.

Untuk menunjang pembinaan yang baik maka perlu didukung dengan sarana dan prasarana yang cukup memadai, pada Lembaga Pemasyarakatan sarana dan prasarana yang menunjang program pembinaan masih dirasa sangat kurang. Hal tersebut jelas sangat mempengaruhi program pembinaan yang akan dijalankan. Seharusnya agar pembinaan berjalan dengan baik pada setiap Lembaga Pemasyarakatan terdapat berbagai macam buku-buku bacaan, khususnya tentang ajaran agama Islam guna menambah wawasan dan pengetahuan ke-Islaman bagi narapidana.Untuk solusi mengatasi masalah sarana dan prasarana yang masih minim tersebut pihak Lembaga Pemasyarakatan bekerja sama dengan berbagai instansi pemerintah maupun non pemerintah. Contohnya akan diusahakan bekerja sama dengan Ormas Islam agar mengadakan perpustakaan keliling guna menambah pengetahuan dan wawasan narapidana. 
c. Partisipasi Masyarakat.

Selama ini peran masyarakat dalam mendukung program pembinaan yang dijalankan oleh pihak Lembaga Pemasyarakatan dirasa masih sangat kurang, padahal salah satu unsur yang paling menentukan dari keberhasilan sebuah pembinaan adalah dengan adanya partisipasi dari masyarakat, oleh karena itu, solusinya untuk menyikapi kurangnya partisipasi dari masyarakat setempat dalam mensukseskan program pembinaan, pihak Lembaga Pemasyarakatan selalu mengadakan pembinaan dan penyuluhan kepada masyarakat sekitar agar lebih peduli pada proses reintegrasi narapidana

Adapun Faktor Penghambat Pembinaan Dengan Sistem Pemasyarakatan Dalam Rangka Pemenuhan Hakhak Narapidana, berdasarkan hasil penelitian yang telah dilakukan baik terhadap narapidana maupun kepada Petugas Lembaga Pemasyarakatan, maka diperoleh adanya beberapa hambatan dalam implementasi hak-hak narapidana. Faktor-faktor penghambat implementasi pelaksanaan hak-hak narapidana di Lembaga Pemasyarakatan, sebagai berikut:

\section{a. Faktor Hukum (Perundang-undangan)}

Berbagai macam hak narapidana yang telah disebutkan di atas, dalam pelaksanaannya membutuhkan syarat administratif yang mutlak harus ada, yaitu petikan putusan (vonis) pengadilan dan berita acara pelaksanaan putusan pengadilan yang dibuat oleh jaksa sebagai eksekutor. Adanya petikan putusan menjadi bukti formal bahwa perkara yang dikenakan terhadap seorang terdakwa telah dikenakan suatu putusan pidana oleh pengadilan, artinya tanpa adanya petikan vonis, maka putusan pengadilan yang menjatuhkan suatu pidana belum dapat dilaksanakan. Sedangkan berita acara pelaksanaan putusan pengadilan yang dikeluarkan oleh jaksa untuk ditanda tangani oleh jaksa yang menangani perkara tersebut, si terpidana dan diketahui oleh Kepala Lapas atau Kepala Rutan, adalah sebagai bukti formal bahwa perkara tersebut sudah berkekuatan hukum tetap (inkracht van gewijsde), dan tidak ada pihak yang mengajukan banding atau kasasi, baik 
jaksa maupun terpidana atau kuasa hukumnya. Dengan bukti petikan vonis dan berita acara pelaksanaan putusan pengadilan, maka seorang terpidana telah sah menjadi narapidana dan kepadanya dapat diberikan hak-hak sesuai peraturan perundang-undangan yang berlaku. Kepala Lapas atau Rutan tidak dapat mengirimkan usulan pemberian hakhak narapidana tanpa disertai copy petikan vonis dan berita acara pelaksanaan putusan pengadilan.

Pembuatan dan pendistribusian petikan putusan pengadilan diatur dalam Pasal $226 \mathrm{KUHAP}$, yang secara lengkap berbunyi sebagai berikut:

(1) Petikan surat putusan diberikan kepada terdakwa atau penasehat hukumnya setelah putusan diucapkan;

(2) Salinan surat putusan pengadilan diberikan kepada penuntut umum dan penyidik, sedangkan kepada terdakwa atau penasehat hukumnya diberikan atas permitaan;

(3) Salinan surat putusan pengadilan hanya boleh diberikan kepada orang lain dengan izin ketua pengadilan setelah mempertimbangkan kepentingan dari permintaan tersebut.

Dari gambaran Pasal 226 KUHAP tersebut dapat dilihat bahwa unsur Rumah Tahanan Negara atau Lembaga Pemasyarakatan tidak disebutkan sebagai pihak yang harus mendapatkan surat petikan putusan atau salinan putusan pengadilan. Hal ini yang sering menimbulkan akibat terjadinya masalah keterlambatan pengiriman petikan vonis dari pengadilan kepada Rutan/Lapas, yang pada akhirnya berdampak kepada terhambatnya implementasi hak-hak para narapidana.

Bunyi Pasal 226 KUHAP ini bila dicermati juga kontradiktif dengan Pasal 555 KUHP. Di satu sisi Pasal 226 KUHAP secara tidak langsung menyatakan bahwa pengadilan tidak ada kewajiban untuk mengirimkan petikan putusan pidana ke Lapas/Rutan, sementara di sisi lain Pasal 555 KUHP menyatakan bahwa Kepala Rumah Penjara tidak boleh menerima orang tahanan tanpa adanya bukti formal (berupa surat perintah penahanan atau surat petikan putusan pidana) yang sah. 
KUHAP yang disebut sebagai karya agung dalam dunia hukum Indonesia, dalam kaitannya dengan pelaksanaan pidana penjara masih mengandung kelemahan. Oleh karena itu, sudah sepatutnya dilakukan revisi terutama Pasal 226 yang seharusnya mencantumkan pihak Rutan/Lapas sebagai pihak yang juga wajib mendapatkan surat petikan putusan dari pengadilan.

Demikian pula lahirnya Undang-Undang Nomor 12 Tahun 1995 Tentang Pemasyarakatan diakui sebagai suatu prestasi di bidang hukum, karena selama kurun waktu 50 tahun sejak Republik Indonesia merdeka dan lebih dari 30 tahun sejak lahirnya sistem pemasyarakatan, pelaksanaan pembinaan narapidana di dalam Lapas tidak mempunyai landasan hukum yang kuat. Reglemen Penjara sebagai salah satu produk hukum jaman Belanda masih digunakan sebagai acuran, ditambah dengan berbagai surat edaran Menteri atau Direktur Jenderal yang bersifat sektoral dan lemah kedudukan hukumnya. Dengan ditetapkannya UndangUndang Pemasyarakatan, secara politik dan hukum telah dapat mengangkat eksistensi Pemasyarakatan, namun substansi dari undang-undang itu sendiri sebenarnya belum bisa dikatakan lengkap. Substansi Undang-Undang Pemasyarakatan lebih banyak mengatur tentang definisi dan klasifikasi dalam lingkup pemasyarakatan, sedangkan materi pembinaannya serta bagaimana hubungan dengan pihak terkait, baik dari instansi pemerintah yang lain, organisasi non-pemerintah, maupun masyarakatan, masih sangat sedikit porsinya. Padahal pembinaan narapidana dengan sistem pemasyarakatan dalam konsepnya mempunyai tujuan memulihkan kesatuan hubungan hidup, kehidupan dan penghidupan narapidana dengan masyarakat, dimana tujuan tersebut dapat tercapai dengan pola pembinaan yang melibatkan masyarakat dan pihak terkait lainnya.

Pola Pembinaan Narapidana/Tahanan yang ditetapkan dengan Keputusan Menteri Kehakiman RI Nomor: M.02-PK.04.10 Tahun 1990, secara substansi sudah cukup baik dan selalu dijadikan acuan dalam pelaksanaan pembinaan narapidana di dalam Lapas/Rutan, namun bila dilihat dari hierarki/tata urutan peraturan perundang- 
undangan sebagaimana diatur dalam Undang-Undang Nomor 10 Tahun 2004, rentang jarak antara Undang-Undang Pemasyarakatan dengan Keputusan Menteri Kehakiman tentang Pola Pembinaan Narapidana/Tahanan ini terlampau jauh. Dengan kata lain, Pola Pembinaan Narapidana/Tahanan sebagai acuan dalam pelaksanaan pembinaan narapidana memerlukan baju hukum yang lebih kuat daripada sekedar Keputusan Menteri.

b. Faktor Budaya

Masyarakat di mana peraturan hukum berlaku atau diterapkan juga mempunyai pengaruh yang kuat terhadap pelaksanaan penegakan hukum. Lembaga Pemasyarakatan sebagai institusi terakhir dalam sistem peradilan pidana sangat memerlukan peran serta masyarakat dalam rangka membantu petugas pemasyrakatan membina dan membimbing narapidana agar dapat menyadari kesalahannya dan pada akhirnya kembali kemasyarakat sebagai manusia yang berguna. Namun pada kenyataannya terdapat beberapa sikap negatif dari masyarakat yang kontra produktif dengan tujuan pembinaan seperti adanya pandangan bahwa lembaga pemasyarakatan adalah wilayah terasing yang tidak boleh didekati karena di dalamnya hanya berisi penjahat dan narapidana itu tidak selayaknya dibina karena perbuatannya telah menimbulkan korban di masyarakat.

Menurut analisa penulis, sikap pandangan yang negatif atau skeptif dari masyarakat tersebut perlu dirubah, karena pemasyarakatan sebagai sistem dalam pelaksanaannya harus melibatkan tiga unsur untuk mencapai tujuan pembinaan, yaitu; unsur narapidana, petugas dan masyarakat. Partisipasi masyarakat sangat penting karena pada akhirnya nanti narapidana akan bebas dan kembali ke tengah masyarakat.

\section{E. SIMPULAN}

Ajaran Agama Islam merupakan salah satu bentuk pembinaan bagi narapidana yang bersifat Ultimum Remidium (upaya terakhir) yang lebih tertuju kepada diri narapidana agar sadarakan perbuatannya sehingga pada saat kembali ke dalam masyarakat ia akanmenjadi baik, baik dari segi keagaman, sosial 
budaya maupun moral sehinggaakan tercipta keserasian dan keseimbangan di tengah-tengah masyarakat.Prinsip pembinaan dengan sebuah pendekatan yang lebih manusiawi tersebut terdapat dalam usaha-usaha pembinaan dengan sistem pemasyarakatanseperti yang diatur dalam Undang-undang Nomor 12 tahun 1995 tentang pemasyarakatan.

Ajaran Agama Islam dengan Pemasyarakatan berarti memasyarakatkan kembali terpidana sehingga menjadi warga yang baik dan berguna ${ }^{23}$, sebagaimana tercantum dalam Undang-undang Nomor 12 Tahun 1995 tentang Pemasyarakatan, bahwa Sistem Pemasyarakatan adalah suatu tatanan mengenai arah dan batas, serta cara pembinaan narapidana (warga binaan) berdasarkan Pancasila yang dilaksanakan secara terpadu antara pembina, yang dibina dan masyarakat, untuk meningkatkan kualitas warga binaan agar menjadi manusia seutuhnya, bertakwa, sehat dan bertanggung jawab pada diri, keluarga dan masyarakat, sehingga dapat mengintegrasikan dirinya ke dalam masyarakat dan dapat kembali berperan sebagai anggota masyarakat yang bebas dan bertanggung jawab.

\section{DAFTAR PUSTAKA}

Adi Sujatno, Sistem Pemasyarakatan Indonesia (Membangun Manusia Mandiri), Direktorat Jenderal Pemasyarakatan, Jakarta, 2004.

Andi Hamzah, Hukum Acara Pidana Indonesia, Arikha Media Cipta, Jakarta, 1993

Sistem Pidana dan Pemidanaan, Pradnya Paramita, Jakarta, 1985.

Atmowiloto, Ariswindo, Hak-hak Narapidana, ELSAM, Jakarta, 1985

${ }^{23}$ Didin Sudirman, Masalah-Masalah Actual Tentang Pemasyarakatan, Pusat Pengembangan Kebijakan Departemen Hukum Dan Hak Asasi Manusia, Gandul Cinere Depok, 2006, h. 5 
Widiada Gunakaya, Sejarah dan Konsepsi Pemasyarakatan, Armico, Bandung, 1988

Badan Pembinaan Hukum Nasional Departemen Kehakiman, Pertemuan Ilmiah Tentang Pola Pembinaan, Penerimaan Berkas Narapidana dan Pemberian Santunan Terhadap Korban Tindak Pidana, Jakarta, 1994.

Bambang Poernomo, Pelaksanaan Pidana Penjara dengan Sistem: Pemasyarakatan di Indonesia, Bina Cipta, Jakarta, 1985.

B.N. Marbun. 2003. Kamus Politik. Jakarta. Sinar Harapan.

CI. Harsono, Sistem Baru Pembinaan Narapidana, Djambatan, Jakarta, 1995.

Departemen Kehakiman RI, Pola Pembinaan Narapidana dan Tahanan, Jakarta, 1990.

Departemen Pendidikan dan Kebudayaan. 1998. Kamus Bahasa Indonesia. Jakarta.

Dwija Priyatno, Sistem Pelaksanaan Pidana Penjara di Indonesia, Refika Aditama, Bandung, 2006.

Suyatna, Seluk Beluk Pemasyarakatan, Departemen Kehakiman RI, 1981.

Lawrence M. Friedman, Laur and Society, An Introduction New Jersey Prentice Hall Inc, 1977.

Moelyanto, Azas-azas Hukum Pidana, Bintang Indonesia, Jakarta, 1993

Fungsi dan Tujuan Hukum Pidana Indonesia, dan Rencana Undang-undang Tentang Azas-azas dan Dasar-dasar Pokok Tata Hukum Indonesia, Bina Aksara, Jakarta, 1985.

Muladi dan Arief Barda Nawawi, Teori-teori Kebijakan Pidana, Alumni, Bandung, 1985

Mufham Al-Amin, Manajemen Pengawasan Refleksi dan Kesaksian Seorang Auditor, Kalam Indonesia, Ciputat, 2006.

Petrus Irvan dan Pandapotan Simorangkir, Lembaga Pemasyarakatan dalam Perspektif Sistem Peradilan Pidana. Pusataka Sinar Harapan, Jakarta, 1995 
Prajudi Atmosudirdjo, Administrasi dan Manajemen Umum, Gunung Agung, Jakarta, 2004.

Puspoprodjo, Sejarah dan Konsepsi Pemasyarakatan, Armico, Bandung, 1998.

Racmad Miosutarjo, Peranan Tugas Pemasyarakatan, 2002.

Romli, Atmasasmita, Pengayoman, Penelitian dan Pengembangan Departemen Kehakiman RI, Sinar Grafika, Jakarta, 1984.

Sanusi Husim, Demokrasi Tidak Berhenti di Depan Pintu Gerbang Lembaga Pemasyarakatan. Pidato Pengukuhan Guru Besar Tetap Ilmu Hukum Pidana Fakultas Hukum Universitas Lampung.

Soemadipraja, S. Ahmad dan Romli Atmasasmita, Sistem Pemasyarakatan di Indonesia, Bina Cipta, Jakarta, 1979.

Soerjono Soekanto, Pengantar Penelitian Hukum, UI Press, Jakarta, 1995.

Faktor-faktor yang Mempengaruhi Penegakan Hukum, Rajawali, Jakarta, 2001

Saharjo, Pohon Beringin Pengayoman, Penelitian dan Pengembangan Departemen Kehakiman RI, Sinar Grafika, Jakarta, 1984.

A. Perundang-Undangan

Undang-Undang Dasar 1945.

Undang-Undang Nomor 1 Tahun 1946 Tentang Kitab UndangUndang Hukum Pidana.

Undang-Undang Nomor 8 Tahun 1981 Tentang Kitab UndangUndang Hukum Acara Pidana.

Undang-Undang Nomor 12 Tahun 1995 Tentang Pemasyarakatan.

Peraturan Pemerintah Nomor 27 Tahun 1983 Tentang Pelaksanaan KUHAP.

Peraturan Pemerintah Nomor 31 Tahun 1999 Tentang Pembinaan dan Pembimbingan Warga Binaan Pemasyarakatan. 
Peraturan Pemerintah Nomor 32 Tahun 1999 Tentang Syarat dan Tata cara Pelaksanaan Hak Warga Binaan Pemasyarakatan. Keputusan Presiden RI No. 174 Tahun 1999 tentang Remisi.

Peraturan Menteri Hukum dan HAM RI No. M.PK.01.10 Tahun 2007 tentang Syarat dan Tata Cara Pelaksanaan Asimilasi, Pembebasan Bersyarat, Cuti Menjelang Bebas dan Cuti Bersyarat. 